\section{To: (Receiving Organization) Distribution}

3. From: (Originating Organization)

M. J. Kupfer, LMHC, H5-49 376-6631

6. Design Authority/ Design Agent/Cog.

Tank 241-SX-111

8. Originator Remarks:

\section{In lepporal / Relwee}

11. Receiver Remarks:

11A. Design Baseline Document?

[] Yes

$[\mathrm{X}] \mathrm{No}$ Engr:: M. S. Suefer

4. Related EDT No.:

NA

7. Purchase Order No.:

NA

9. Equip./Component No.: NA

10. System/Bldg_/Facility: NA

12. Major Assm. Dwg. No.: NA

13. Permit/Permit Application No.:

NA

14. Required Response Date:

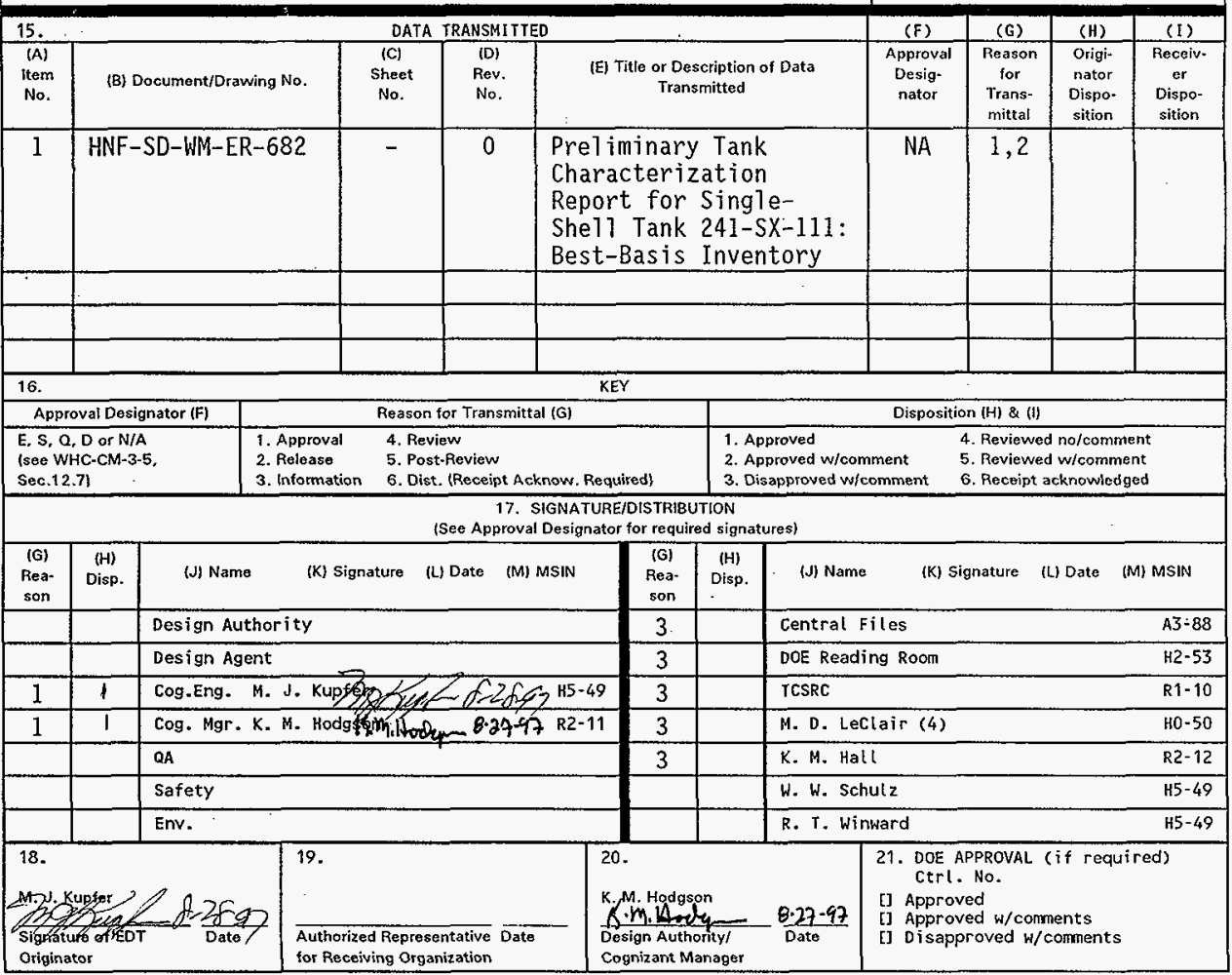

BD-7400-172-2 (05/96) GEF097 


\title{
Preliminary Tank Characterization Report for Single-Shell Tank 241-SX-111: Best-Basis Inventory
}

\author{
W. W. Schulz (W ${ }^{2} S$ Company), R. T. Winward (Meier Associates), and \\ M. J. Kupfer \\ Lockheed Martin Hanford Corporation, Richland, WA 99352 \\ U.S. Department of Energy Contract DE-AC06-96RL13200
}

EDT/ECN: 622670

Org Code: $746 / 0$

UC: 712

B\&R Code: EW3120074

Charge Code: N4G3A

Key Words: TCR, best-basis inventory

Abstract: An effort is underway to provide waste inventory estimates that.will serve as standard characterization source terms for the various waste management activities. As part of this effort, an evaluation of available information for single-shell tank 241-SX-111 was performed, and a best-bas is inventory was established. This work follows the methodology that was established by the standard inventory task.

TRADEMARK DISCLAIMER. Reference herein to any specific commercial product, process, or service by trade name, trademark, manufacturer, or otherwise, does not necessarily constitute or imply its endorsement, recommendation, or favoring by the United States Government or any agency thereof or its contractors or subcontractors.

Printed in the United States of America. To obtain copies of this document, contact: Document Control Services, P.O. BoK 950, Mailstop H6-08, Richland WA 99352, Phone (509) 372-2420;

Fax (509) $376-4989$.
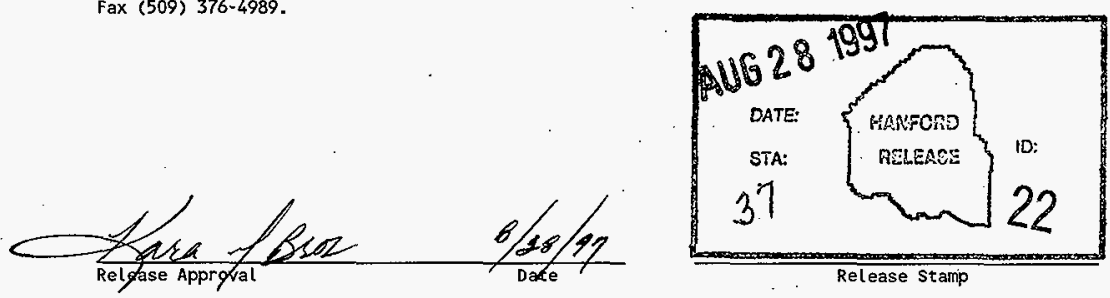


\title{
PRELIMINARY TANK CHARACTERIZATION REPORT FOR SINGLE-SHELL TANK 241-SX-111: BEST-BASIS INVENTORY
}

August 1997

\author{
M. J. Kupfer \\ Lockheed Martin Hanford Corporation \\ Richland, Washington \\ W. W. Schulz \\ $\mathrm{W}^{2} \mathrm{~S}$ Company \\ Albuquerque, New Mexico \\ R. T. Winward \\ Meier Assoicates \\ Richland, Washington
}

Prepared for

U.S. Department of Energy

Richland, Washington 
HNF-SD-WM-ER-682

Revision 0

This page intentionally left blank. 


\section{PRELIMINARY TANK CHARACTERIZATION REPORT \\ FOR SINGLE-SHELL TANK 241-SX-111: \\ BEST-BASIS INVENTORY}

This document is a preliminary Tank Characterization Report (TCR). It only contains the current best-basis inventory (Appendix D) for single-shell tank 241-SX-111. No TCRs have been previously issued for this tank, and current core sample analyses are not available. The best-basis inventory, therefore, is based on an engineering assessment of waste type, process flowsheet data, early sample data, and/or other available information.

The Standard Inventories of Chemicals and Radionuclides in Hanford Site Tank Wastes (Kupfer et al. 1997) describes standard methodology used to derive the tank-by-tank best-basis inventories. This preliminary TCR will be updated using this same methodology when additional data on tank contents become available.

\section{REFERENCE}

Kupfer, M. J., A. L. Boldt, B. A. Higley, K. M. Hodgson, L. W. Shelton, B. C. Simpson, and R. A. Watrous (LMHC), S. L. Lambert, and D. E. Place (SESC), R. M. Orme (NHC), G. L. Borsheim (Borsheim Associates), N. G. Colton (PNNL), M. D. LeClair (SAIC), R. T. Winward (Meier Associates), and W. W. Schulz (W² Corporation), 1997, Standard Inventories of Chemicals and Radionuclides in Hanford Site Tank Wastes, HNF-SD-WM-TI-740, Rev. 0, Lockheed Martin Hanford Corporation, Richland, Washington. 
HNF-SD-WM-ER-682

Revision 0

This page intentionally left blank. 
HNF-SD-WM-ER-682

Revision 0

\section{APPENDIX D}

\section{EVALUATION TO ESTABLISH BEST-BASIS INVENTORY FOR SINGLE-SHELL . TANK 241-SX-111}


HNF-SD-WM-ER-682

Revision 0

This page intentionally left blank. 
HNF-SD-WM-ER-682

Revision 0

APPENDIX D

EVALUATION TO ESTABLISH BEST-BASIS INVENTORY

FOR SINGLE-SHELL TANK 241-SX-111

An effort is underway to provide waste inventory estimates that will serve as standard characterization source terms for the various waste management activities (Hodgson and LeClair 1996). As part of this effort, an evaluation of available information for single-shell tank 241-SX-111 was performed and a best-basis inventory was established. This work, detailed in the following sections, follows the methodology that was established by the standard inventory task.

The following sections establish a best-basis inventory estimate for chemical and radionuclide components in tank 241-SX-111. A complete list of data sources and inventory evaluations is provided at the end of this section.

\section{D1.0 CHEMICAL INFORMATION SOURCES}

The waste in tank 241-SX-111 has not been core sampled and analyzed. A TCR for tank 241-SX-111 has not been prepared. The Hanford Defined Waste (HDW) model report (Agnew et al. 1997) provides tank content estimates in terms of component concentrations and inventories.

Composition data for a sludge sample from tank 241-SX-111 are reported by Allen (1976). These data are not used here in determination of the best-basis estimate of the analyte inventory in tank 241-SX-111 since the pedigree of the sample analysis reported by Allen (1976) is in serious question.

Tank 241-SX-111 is a known leaker. However, the quantity of material lost to the soil column is currently unknown. No attempt has been made in this assessment to correct for materials lost to the soil column. 
HNF-SD-WM-ER-682

Revision 0

This page intentionally left blank. 
HNF-SD-WM-ER-682

Revision 0

\section{D2.0 COMPARISON OF COMPONENT INVENTORY VALUES}

Hanlon (1996) states that tank 241-SX-111 contains $473 \mathrm{~kL}$ (125 kgal) of solids, $26.5 \mathrm{~kL}$ (7 kgal) of drainable liquid and no pumpable liquid. Agnew et al. (1997) concur with Hanlon's estimate. According to the HDW model (Agnew et al. 1997), the solid waste in tank 241-SX-111 contains $31.1 \mathrm{wt} \%$ water and has a density of $1.74 \mathrm{~g} / \mathrm{cc}$. As described more fully later, Agnew et al. hypothesize that the solids in tank 241-SX-111 derive from both reduction and oxidation (REDOX) process high-level waste (HLW) and salt cake produced from concentrated REDOX process supernatant liquid added to the tank. An independent analysis of historical waste transaction data, conducted in connection with preparation of this section, indicates that all the solid waste in tank 241-SX-111 derives only from REDOX process HLW. As explained in detail later, the completeness and quality of the historical waste transaction data are insufficient to allow an unequivocal determination of the origin of the solid wastes now in tank 241-SX-111.

HDW model predictions of the inventory of the various analytes in tank 241-SX-111 are listed in Table D2-1. (The chemical species are reported without charge designation per the best-basis inventory convention.)

Table D2-1. Estimated Analyte Inventories for Tank 241-SX-111. (2 Sheets)

\begin{tabular}{|c|c|}
\hline Analyte & $\begin{array}{c}\text { HDW model } \\
(\mathrm{kg})\end{array}$ \\
\hline $\mathrm{Al}$ & 79,300 \\
\hline $\mathrm{Bi}$ & 0.228 \\
\hline $\mathrm{Ca}$ & 5,050 \\
\hline $\mathrm{Cl}$ & 1,340 \\
\hline $\mathrm{CO}_{3}$ & 7,600 \\
\hline $\mathrm{Cr}$ & 7,840 \\
\hline $\mathrm{F}$ & 1.07 \\
\hline $\mathrm{Fe}$ & 32,400 \\
\hline $\mathrm{Hg}$ & 0.0344 \\
\hline $\mathrm{K}$ & 340 \\
\hline $\mathrm{Mn}$ & 0.437 \\
\hline $\mathrm{Na}$ & 93,600 \\
\hline $\mathrm{Ni}$ & 1,690 \\
\hline
\end{tabular}




\section{HNF-SD-WM-ER-682}

Revision 0

Table D2-1. Estimated Analyte Inventories for Tank 241-SX-111. (2 Sheets)

\begin{tabular}{|c|c|}
\hline Analyte & $\begin{array}{c}\text { HDW model } \\
(\mathrm{kg})\end{array}$ \\
\hline $\mathrm{NO}_{2}$ & 35,600 \\
\hline $\mathrm{NO}_{3}$ & 104,000 \\
\hline $\mathrm{OH}$ & 212,000 \\
\hline $\mathrm{Pb}$ & 5.64 \\
\hline $\mathrm{PO}_{4}$ & 6.71 \\
\hline $\mathrm{P}$ & $\mathrm{NR}$ \\
\hline $\mathrm{S}$ & $\mathrm{NR}$ \\
\hline $\mathrm{Si}$ & 2,690 \\
\hline $\mathrm{SO}$ & 1,040 \\
\hline $\mathrm{Sr}$ & 0 \\
\hline $\mathrm{TOC}$ & 14.3 \\
\hline $\mathrm{Zn}$ & $\mathrm{NR}$ \\
\hline $\mathrm{Zr}$ & 0.00994 \\
\hline${ }^{239} \mathrm{Pu}$ & \\
\hline${ }^{238} \mathrm{U}$ & $313 \mathrm{Ci}$ \\
\hline Radionuclides & \\
\hline & \\
\hline
\end{tabular}

$\mathrm{HDW}=$ Hanford Defined Waste

$\mathrm{NR}=$ Not reported

${ }^{2}$ Agnew et al. (1997)

becayed to January 1, 1994. 
HNF-SD-WM-ER-682

Revision 0

\section{D3.0 COMPONENT INVENTORY EVALUATION}

The following evaluation of tank contents is performed to identify potential errors and/or missing information that would have an effect upon the HDW model component inventories.

\section{D3.1 CONTRIBUTING WASTE TYPES}

Tank 241-SX-111 is the second (million gallon) tank in a cascade that includes tanks 241-SX-110 and 241-SX-112. Tank 241-SX-111 was constructed in the early 1950s and was designed to be a self-boiling tank with the condensate directed back to the tank. Tank 241-SX-111 was connected to an exhauster.

High-level REDOX process waste (R) was first added to tank 241-SX-111 in 1956. In 1959, 1964, and 1965, tank 241-SX-111 received additional REDOX process HLW (R2) (Agnew et al. 1995, Anderson 1990). In 1965 tank 241-SX-111 also received a one-time addition of concentrated REDOX process HLW supernatant liquid. All the high-level REDOX process waste additions are known or are believed to have contributed to the solid waste $(473 \mathrm{~kL}$ [125 kgal]) now stored in tank 241-SX-111. Beyond such waste additions, there were many liquid transfers into and out of tank 241-SX-111 including water, condensate from self-boiling tanks including tank 241-SX-111, and supernatant liquid from other SX Tank Farm tanks. These latter liquid additions are thought to have significantly reduced the volume of REDOX process salt cake in tank 241-SX-111 as discussed in more detail later in this section.

Table D3-1 provides a summary of the transactions that may have contributed to the type and volume of wastes now in tank 241-SX-111. These values are taken from the more detailed records of waste transactions compiled by Anderson (1990) and Agnew et al. (1995).

Careful review and analysis of the data summarized in Table D3- 1 and other data of Anderson (1990) and Agnew et al. (1995) leads to two possible ways of accounting for the solid waste presently residing in tank 241-SX-111. One of these is published in the HDW model (Rev. 4) Agnew et al. (1997) report. Agnew et al. accept that the volume (measured) of waste now in tank 241-SX-111 is $473 \mathrm{~kL}(125 \mathrm{kgal})$. They partition the amount of solid waste into three types:

- $159 \mathrm{~kL}$ (42 kgal) solids (4.4 vol\% of 3,645 kL (963 kgal)) of R1 type waste (REDOX high-level waste generated between 1952 to 1957)

- $155 \mathrm{~kL}$ (41 kgal) solids (2.3 vol\% of 6,846 (1809 kgal)) of R2 type waste (REDOX high-level waste generated between 1958 to 1966)

- $159 \mathrm{~kL}$ (42 kgal) of REDOX process salt cake (R SltCk). 
HNF-SD-WM-ER-682

Revision 0

Table D3-1. Summary of Contributing Waste Types for Tank 241-SX-111, a,

\begin{tabular}{|c|c|c|}
\hline \multirow{2}{*}{ Historical waste transaction } & \multicolumn{2}{|c|}{ Waste type } \\
\cline { 2 - 3 } & $\mathrm{R}^{\mathrm{c}}$ & $\mathrm{R} \mathrm{SltCk}^{\mathrm{d}}$ \\
\hline Volume waste added, kL (kgal) & $3,645(963)$ & \\
\hline 1956 & $3,013(796)$ & \\
\hline 1959 & $1,014(268)$ & $2,070(547)$ \\
\hline 1964 & $2,820(745)$ & \\
\hline 1965 & \multicolumn{3}{|}{} \\
\hline Volume solids, kL (kgal) & $160(42.4)^{\mathrm{e}}$ & \\
\hline 1956 & $133(35.0)^{\mathrm{e}}$ & \\
\hline 1959 & $44.6(11.8)^{\mathrm{e}, \mathrm{f}}$ & \\
\hline 1964 & $124(32.8)^{\mathrm{e}, \mathrm{f}}$ & $159(42)$ \\
\hline 1965 & & \\
\hline
\end{tabular}

${ }^{2}$ From Agnew et al. (1997)

b From Anderson (1990)

' Neutralized Reduction and Oxidation (REDOX) Process high-level waste (R)

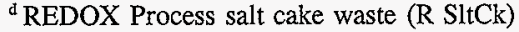

${ }^{\mathrm{e}} 4.4 \mathrm{vol} \%$ of added volume of REDOX process high-level waste

${ }^{\text {f }}$ Agnew et al. (1997) assumed 2.3 vol\% solids from added REDOX process high-level waste.

An alternative way of accounting for the solid waste now in tank 241-SX-111 involves the following analysis and evaluation:

- $159 \mathrm{~kL}$ ( $42 \mathrm{kgal}$ ) solids ( $4.4 \mathrm{vol} \%$ of $3,645 \mathrm{k} \mathrm{L}$ [ $963 \mathrm{kgal}$ ) of REDOX process HLW produced under the conditions of REDOX process Flowsheet 5 , Kupfer et al. (1997).

- $\quad 178.6 \mathrm{~kL}$ (47.2 kgal) solids (4.4 vol\% of 4,114 kL [1,064 kgal]) of REDOX process HLW produced under the conditions of REDOX process Flowsheet 6 , Kupfer et al. (1997).

- $124 \mathrm{~kL}$ ( $32.8 \mathrm{kgal})$ of solids (4.4 vol\% of $2,819 \mathrm{~kL}$ [745 kgal]) of REDOX process HLW produced under the conditions of REDOX Process Flowsheets 7 and 8, Kupfer et al. (1997).

- Negligible volume of REDOX process salt cake. 


\section{Revision 0}

The second alternative accounts for $462 \mathrm{~kL}$ (122 kgal) of solid waste in tank $241-\mathrm{SX}-111$ versus the measured $473 \mathrm{~kL}$ (125) kgal. The difference of $11 \mathrm{~kL}$ ( $3 \mathrm{kgal}$ ) is believed to be within volume measurement error. Alternatively, some compaction of the hydrous solids likely occurred over time. The volume difference may also be accounted for, in part, by a slight understatement, i.e., $4.4 \mathrm{vol} \%$ versus $4.5 \mathrm{vol} \%$, in the volume of solids precipitated from the neutralized REDOX process HLW. The 4.4 vol\% value is retained in this section to be consistent with other sections of this report dealing with tanks containing REDOX process HLW.

In agreement with Agnew et al. (1997) we think $160 \mathrm{~kL}$ (42.4 kgal) of solids resulted from REDOX process HLW generated in 1956. This volume of solids is equivalent to $4.4 \mathrm{vol} \%$ of the total volume of waste added to the tank in this time frame period. Further, we also believe $4.4 \mathrm{vol} \%$ ( $301 \mathrm{~kL}=79.6 \mathrm{kgal})$ of solid waste resulted from the addition of REDOX process HLW added to tank 241-SX-111 in the period 1959 through 1965. The composition of REDOX process HLW produced in these latter years was almost identical to that produced in 1956, at least for iron and other constituents that precipitated when the waste was made alkaline. There is no evidence to support the Agnew et al. contention that the volume of solids precipitated from REDOX process HLW produced in the years 1959 through 1965 was substantially less, 2.3 vol\% versus 4.4 vol\%, than the volume of solids precipitated from REDOX process HLW generated in 1956.

In $1965,2,070 \mathrm{~kL}$ (547 kgal) of evaporated REDOX process HLW supernate liquid were added to tank 241-SX-111. This volume of waste contained, according to Agnew et al. (1997), about $7.77 \mathrm{vol} \%$ of solids ( $161 \mathrm{~kL}=42.5 \mathrm{kgal})$. In applying the HDW model to tank 241-SX-111, Agnew et al. assumed that the REDOX process salt cake solids added in 1965 are still present in the tank. This assumption could be in error since it ignores the large amounts of water and dilute supernatant liquids added to the tank in the years subsequent to the addition of the evaporated HLW supernatant.

For example, in the period 1966 to 1969,$2 ; 558 \mathrm{~kL}$ (676 kgal) of water were added to the tank. In the same time period, $4,600 \mathrm{~kL}(1,216 \mathrm{kgal})$ of dilute supernatant liquids from other tanks were added to tank 241-SX-111. Previous laboratory experience (Schulz 1980) has shown that actual REDOX process salt cake is readily soluble in water. Thus, for the purposes of this independent engineering assessment, it is judged that all the salt cake solids present in the tank in 1965 were dissolved by the time the last liquid was pumped from the tank in 1974. This judgement is made even though it is recognized that much of the liquid added to tank 241-SX-111 boiled off and that water added to the tank served only to maintain a constant liquid level. The liquids added to the tank were not saturated in salts and, therefore, could and, it is believed, did dissolve all the soluble salt cake solids.

In summary, whereas Agnew et ai. (1997), in the HDW model report (Rev. 4), conclude that salt cake solids are present in tank 241-SX-111 the engineering assessment described in this Section concludes that such solids are not present. Obviously, both conclusions cannot be correct. The available historical waste transaction history (Anderson 1990, Agnew et al. 1995) are not sufficient to decide between the two 


\section{Revision 0}

conclusions. Final resolution of the issues will be possible only when (and if) the waste solids in tank 241-SX-111 are sampled and analyzed.

Expected Solids in Waste

Andersón (1990): R

Agnew et al. (1997): R1, R2, R SltCk

This Evaluation: R

$\mathrm{R}=$ Reduction and Oxidation (REDOX) Process high-level waste

R1 = REDOX high-level waste generated between 1952 to 1957

R2 = REDOX high-level waste generated between 1958 to 1966

$\mathrm{R}$ SltCk $=$ REDOX Process salt cake waste

\section{Predicted Current Inventory}

Agnew et al. (1997)

Waste Type

R1

R2

R SltCk

Hanlon (1996)

Waste Type

Sludge

This Evaluation

Waste Type

R (1956)

R (1959)

R (1964)

R (1965)
Waste Volume $473 \mathrm{~kL}$ (125 kgal)

$159 \mathrm{~kL}(42 \mathrm{kgal})$

$155 \mathrm{~kL}(41 \mathrm{kgal})$

$159 \mathrm{~kL}$ (42 kgal)

Waste Volume $473 \mathrm{~kL}$ (125 kgal)

Waste Volume $462 \mathrm{~kL}$ (122 kgal)

$159 \mathrm{~kL}$ (42 kgal)

$133 \mathrm{~kL}(35.4 \mathrm{kgal})$

$44.6 \mathrm{~kL}(11.8 \mathrm{kgal})$

$124 \mathrm{~kL}(32.8 \mathrm{kgal})$

\section{D3.2 EVALUATION OF TECHNICAL FLOWSHEET INFORMATION}

In Table D3-2 (reproduced from information in Kupfer et al. 1997) are listed compositions for REDOX process HLW produced according to Flowsheets 5, 6, 7, and 8 . Note that the composition of REDOX process R1 and R2 waste (Agnew et al. [1997] designations) are listed in Table B3-1 of the best-basis inventory writeup for tank 241-SX-108 (Kupfer and Schulz 1997). An average of the flowsheet values is used for the composition of HLW produced by the REDOX process in 1965. 
Table D3-2. Composition of Reduction and Oxidation Process High-Level Waste. ${ }^{a}$

\begin{tabular}{|c|c|c|c|}
\hline Composition $M$ & \multicolumn{3}{|c|}{ REDOX process high-level waste } \\
\hline Analyte & Flowsheet 5 & Flowsheet 6 & Flowsheets 7 and $8^{\circ}$ \\
\hline $\mathrm{Al}$ & 1.29 & 0.95 & 1.10 \\
\hline $\mathrm{Bi}$ & 0 & $4.9 \mathrm{E}-05$ & $3.5 \mathrm{E}-04$ \\
\hline $\mathrm{Cr}$ & 0.17 & 0.13 & 0.21 \\
\hline $\mathrm{Fe}$ & 0.0074 & 0.0075 & 0.018 \\
\hline $\mathrm{I}$ & 0 & $4.3 \mathrm{E}-05$ & $6.7 \mathrm{E}-05$ \\
\hline $\mathrm{K}$ & 0.0034 & $0.0034^{\circ}$ & 0 \\
\hline $\mathrm{Mn}$ & 0.0034 & $0.0034^{\circ}$ & 0 \\
\hline $\mathrm{Na}$ & 7.1 & 7.3 & 6.8 \\
\hline $\mathrm{NO}$ & 4.3 & 3.8 & 5.0 \\
\hline $\mathrm{Oxalate}_{3}$ & 0.0077 & 0.0080 & 0.013 \\
\hline $\mathrm{SO}_{4}$ & 0.023 & 0.022 & 0.036 \\
\hline $\mathrm{U}^{\mathrm{d}}$ & 0.0037 & $6.6 \mathrm{E}-04$ & $7.76 \mathrm{E}-04$ \\
\hline Issue Date & $8 / 55$ & $10 / 60$ & $1 / 65$ \\
\hline
\end{tabular}

REDOX $=$ Reduction and oxidation

a Adapted from tables in Kupfer et al. (1997)

${ }^{b}$ Average of values shown in Flowsheets 7 and 8 .

${ }^{c}$ Not shown on published flowsheet, Kupfer et al. (1997) but $\mathrm{KMnO}_{4}$ usage in REDOX plant is known to have continued until the fall of 1959

¿ Table D1-2,Kupfer et al. (1997).

The composition listed in Table D3-2 for REDOX process Flowsheet 6, Kupfer et al. (1997), HLW specifies that the waste contained $0.0034 \mathrm{M}$ KMnO4. The published version of Flowsheet 6, Kupfer et al. (1997), does not include any mention of KMnO4; information presented elsewhere in Kupfer et al. 1997 indicates that $\mathrm{KMnO}_{4}$ was used in the REDOX process through most of 1959 . Also, note as mentioned previously, that REDOX process HLW generated under either the conditions of Flowsheets 5, 6, 7, and 8, Kupfer et al. (1997) contained almost identical concentrations of precipitable metals, e.g., $\mathrm{Fe}, \mathrm{Mn}, \mathrm{Bi}$, and U. 


\section{D3.3 PREDICTED WASTE INVENTORIES}

This section presents results of an engineering assessment of the inventories of the various analytes in tank 241-SX-111 waste. A set of simplified assumptions forms the basis for the independent assessment. The assumptions and observations are based upon best technical judgement pertaining to parameters that can significantly influence tank inventories. These parameters include: (a) correct predictions of contributing waste types, (b) accurate predictions of model flowsheet conditions, fuel processed, and waste volumes, (c) accurate prediction of component solubilities, and (d) accurate predictions of physical parameters such as density, percent solids, void fraction (porosity), etc. Of course, as necessary, the assumptions used can be modified to provide a basis for identifying potential errors and /or missing information that could influence either or both sampling-and model-based inventories. The simplified assumptions and observations used for predicting the inventory of several analytes in tank 241-SX-111 are as follows:

1. Only the neutralized REDOX process HLW introduced into tank 241-SX-111 contributed to solids formation. Condensates, water, and waste supernatants, either concentrated or dilute, from other SX Tank Farm tanks or evaporators added to tank 241-SX-111 did not contribute any solid waste to the inventory presently in tank 241-SX-111.

2. For all REDOX process HLW added to tank $241-$ SX-111 the volume of precipitated solids was $4.4 \mathrm{vol} \%$ of the total volume of waste slurry.

3. All Bi, Fe, Mn, and $U$ in the REDOX process HLW added to tank 241-SX-111 precipitated as solid compounds.

4. Aside from $\mathrm{Bi}, \mathrm{Fe}, \mathrm{Mn}$, and $\mathrm{U}$ in the REDOX process HLW, all the other analytes partitioned to some extent between solid and liquid phases.

5. Essentially all solid sodium salts, i.e., salt cake, added to the tank in 1965 dissolved in water and other aqueous solutions that were subsequently added to tank 241-SX-111.

6. The concentration of analytes in the REDOX process sludge in tank 241-SX-111 is assumed to be the same as the average concentration of the same analytes in sludge in tanks 241-S-101 Kruger et al. (1996), 241-S-104 DiCenso et al. (1994), and 241-S-107 Simpson et al. (1996).

7. The waste transaction history and waste volume information for tank 241-SX-111 provided in Agnew et al. (1995) is assumed to be correct.

8. Radiolysis of $\mathrm{NO}_{3}$ to $\mathrm{NO}_{2}$ and any additions of nitrite to wastes in tank 241-SX-111 for corrosion control purposes are not accounted for in this independent assessment. 
HNF-SD-WM-ER-682

Revision 0

9. The estimated mass of solids in tank 241-SX-111 provided by Agnew et al. (1997) is assumed to be correct

\section{D3.4 PREDICTED INVENTORY OF ANALYTES IN TANK 241-SX-111}

The contributions to inventory from REDOX process HLW, which are determined by two different methods, follows.

\section{D3.4.1 Application of Analytical Data for Wastes in Tanks 241-S-101, 241-S-104, and 241-S-107}

Table D3-3 lists concentration data determined for samples of sludge from tanks 241-S-101 Kruger et al. (1996), 241-S-104 DiCenso et al. (1994), and 241-S-107 Simpson et al. (1996). Also listed in Table D3-3 are the average concentrations $(\mu \mathrm{g} / \mathrm{g})$ for many of the analytes in these tanks. Convincing arguments made in TCRs for tanks 241-S-101 Kruger et al. (1996), 241-S-104 DiCenso et al. (1994), and 241-S-107 Simpson et al. (1996) show that the sludge in these tanks derives solely from REDOX process HLW (Hu et al. 1997). The average concentration $(\mu \mathrm{g} / \mathrm{g})$ of analytes determined in tanks 241-S-101, 241-S-104, and 241-S-107 is thought to also represent the composition of the REDOX process HLW sludge in tank 241-SX-111.

The inventory of various analytes in tank 241-SX-111 is calculated by multiplying each of the average analyte concentrations listed in Table D3-3 by $8.22 \mathrm{E}+05 \mathrm{~kg}$, the mass of solid waste stated (Agnew et al. 1997) to be in tank 241-SX-111. Results of these computations are shown in Table D3-4.

Table D3-3. R1 Sludge Concentration Estimate. (3 Sheets)

\begin{tabular}{|c|c|c|c|c|c|}
\hline Analyte & $\begin{array}{c}241-\mathrm{S}-101 \\
\text { segments } \\
7 \mathrm{U}-8 \mathrm{~L}^{\mathrm{a}} \\
(\mu \mathrm{g} / \mathrm{g})\end{array}$ & $\begin{array}{c}241-\mathrm{S}-104 \\
\text { (total sludge }_{\text {concentration) }}^{\mathrm{b}} \\
(\mu \mathrm{g} / \mathrm{g})\end{array}$ & $\begin{array}{c}241-\mathrm{S}-107 \\
\text { segments }^{\mathrm{g}} \\
(\mu \mathrm{g} / \mathrm{g})\end{array}$ & $\begin{array}{c}\text { Average } \\
\text { Concentration } \\
\mathrm{d}(\mu \mathrm{g} / \mathrm{g})\end{array}$ & $\begin{array}{c}\text { HDW } \\
\text { layer } \\
\text { concentration } \\
\text { for tank } \\
241-\mathrm{SX}-111 \\
(\mu \mathrm{g} / \mathrm{g})\end{array}$ \\
\hline $\mathrm{Al}$ & 127,000 & 117,000 & 56,400 & 100,000 & 96,500 \\
\hline $\mathrm{Bi}$ & $<38.8$ & $<45.7$ & $\mathrm{NR}$ & $<42.2$ & 0.278 \\
\hline $\mathrm{Ca}$ & 322 & 247 & 234 & 268 & 6,140 \\
\hline $\mathrm{Cl}$ & 2,050 & 3,200 & 1,860 & 2,370 & 1,630 \\
\hline $\mathrm{Cr}$ & 2,230 & 2,350 & 1,180 & 1,920 & 9,540 \\
\hline $\mathrm{F}$ & $<65.7$ & 145 & 150 & $<120$ & 1.30 \\
\hline
\end{tabular}


Revision 0

Table D3-3. R1 Sludge Concentration Estimate. (3 Sheets)

\begin{tabular}{|c|c|c|c|c|c|}
\hline Analyte & $\begin{array}{c}241-S-101 \\
\text { segments } \\
7 \mathrm{U}-8 \mathrm{~L}^{\mathrm{a}} \\
(\mu \mathrm{g} / \mathrm{g})\end{array}$ & $\begin{array}{c}241-\mathrm{S}-104 \\
\text { (total sludge } \\
\text { concentration) }^{\mathrm{b}} \\
(\mu \mathrm{g} / \mathrm{g})\end{array}$ & $\begin{array}{c}241-\mathrm{S}-107 \\
\text { segments }^{\circ} \\
(\mu \mathrm{g} / \mathrm{g})\end{array}$ & $\begin{array}{c}\text { Average } \\
\text { Concentration } \\
{ }^{\mathrm{d}}(\mu \mathrm{g} / \mathrm{g})\end{array}$ & $\begin{array}{c}\mathrm{HDW}^{\mathrm{e}} \text { sludge } \\
\text { layer } \\
\text { concentration } \\
\text { for tank } \\
241-\mathrm{SX}-111 \\
(\mu \mathrm{g} / \mathrm{g})\end{array}$ \\
\hline $\mathrm{Fe}$ & 1,960 & 1,720 & 1,160 & 1,613 & 39,400 \\
\hline $\mathrm{Hg}$ & NR & $<0.126$ & NR & $<0.126$ & 0.042 \\
\hline K & 539 & 300 & 457 & 432 & 414 \\
\hline $\mathrm{La}$ & $<19.5$ & $<2.07$ & NR & $<10.8$ & 4.55 E-07 \\
\hline $\mathrm{Mn}$ & 2,750 & 1,150 & 83 & 1,330 & 0.531 \\
\hline $\mathrm{Na}$ & 112,000 & 121,000 & 60,400 & 97,800 & 114,000 \\
\hline $\mathrm{Ni}$ & 90.7 & 56 & 206 & 118 & 2,050 \\
\hline $\mathrm{NO}_{2}$ & 31,100 & 25,900 & 34,300 & 30,433 & 43,300 \\
\hline $\mathrm{NO}_{3}$ & 119,000 & 191,000 & 57,600 & 122,500 & 126,000 \\
\hline $\mathrm{Pb}$ & 37 & 29.6 & 33 & 33.2 & 6.85 \\
\hline $\mathrm{PO}_{4}$ & 1,360 & $<2,190$ & 1,630 & $<1,730$ & 8.16 \\
\hline $\mathrm{Si}$ & 1,360 & 1,330 & 1,060 & 1,250 & 3,280 \\
\hline $\mathrm{SO}_{4}$ & 897 & 2,270 & 1,300 & 1,489 & 1,270 \\
\hline $\mathrm{Sr}$ & 456 & 424 & 378 & 420 & 0 \\
\hline $\begin{array}{c}\text { TIC as } \\
\mathrm{CO}_{3}\end{array}$ & NR & 4,140 & NR & 4,140 & 9,250 \\
\hline TOC & NR & 1,730 & NR & 1,730 & 17.4 \\
\hline $\mathrm{U}$ & 7,684 & 6,690 & 8,685 & 7,690 & 760 \\
\hline $\mathrm{Zr}$ & 36 & 33.6 & 131 & 66.9 & 0.0121 \\
\hline \multicolumn{6}{|c|}{ Radionuclides $^{f}(\mu \mathrm{Ci} / \mathrm{g})$} \\
\hline${ }^{90} \mathrm{Sr}$ & NR & 301 & 276 & 288 & 2,580 \\
\hline${ }^{137} \mathrm{Cs}$ & 98 & 60.5 & 74 & 77.6 & 123 \\
\hline
\end{tabular}


HNF-SD-WM-ER-682

Revision 0

Table D3-3. R1 Sludge Concentration Estimate. (3 Sheets)

\begin{tabular}{|c|c|c|c|c|c|}
\hline Analyte & $\begin{array}{c}241-\mathrm{S}-101 \\
\text { segments } \\
7 \mathrm{U}-8 \mathrm{~L}^{\mathrm{a}} \\
(\mu \mathrm{g} / \mathrm{g})\end{array}$ & $\begin{array}{c}241-\mathrm{S}-104 \\
\text { (total sludge } \\
\text { concentration) } \\
(\mu \mathrm{g} / \mathrm{g})\end{array}$ & $\begin{array}{c}241-\mathrm{S}-107 \\
\text { segments }^{\mathrm{e}} \\
(\mu \mathrm{g} / \mathrm{g})\end{array}$ & $\begin{array}{c}\text { Average } \\
\text { Concentration } \\
\mathrm{d}(\mu \mathrm{g} / \mathrm{g})\end{array}$ & $\begin{array}{c}\text { HDW } \\
\text { layer } \\
\text { concentration } \\
\text { for tank } \\
241-\mathrm{SX}-111 \\
(\mu \mathrm{g} / \mathrm{g})\end{array}$ \\
\hline $\begin{array}{c}\text { density } \\
(\mathrm{g} / \mathrm{mL})\end{array}$ & 1.77 & 1.64 & 1.90 & 1.77 & 1.74 \\
\hline
\end{tabular}

HDW $=$ Hanford Defined Waste

NR $=$ Not reported

REDOX $=$ Reduction oxidation process

$\mathrm{R} 1=$ REDOX waste generated between 1952 and 1957

${ }^{2}$ Kruger et al. (1996)

${ }^{b}$ DiCenso et al. (1994)

'Statistically determined median R1 sludge concentrations for tank 241-S-107 contained in the attachment to Simpson et al. (1996)

${ }^{\circ}$ Average of analyte concentrations for tank 241-S-101, 241-S-104, and 241-S-107

'Agnew et al. (1997)

${ }^{\mathrm{f}}$ Radionuclides decayed to January 1, 1994.

\section{D3.4.2 Alternative Calculation Method for Inventory of Analytes Assumed to Completely Precipitate}

Inventories of iron, manganese, bismuth, and uranium added to tank 241-SX-111 were calculated separately for the periods: 1956, 1959, 1964, and 1965.

These calculations use data presented in Tables D3-1 and D3-2. Inventories $(\mathrm{kg})$ of each analyte were calculated as the product of the following factors:

- Volume (kgal) of waste slurry added to tank in respective times periods (Table D3-1)

- Molarity of analyte in waste stream (Table D3-2)

- Atomic weight of analyte $(\mathrm{g})$

- $1.0 \mathrm{E}+03 \mathrm{gal} / \mathrm{kgal}-$-conversion factor

- $3.785 \mathrm{~L} /$ gal--conversion factor

- $\mathrm{Kg} / 1.0 \mathrm{E}+03 \mathrm{~g}$--conversion factor. 
HNF-SD-WM-ER-682

Revision 0

Results of these calculations are summarized below; in all cases, quantities are given as $\mathrm{kg}$.

1956

Iron:

$963 \mathrm{kgal} \times 0.0074 \mathrm{~mole} / \mathrm{L} \times 3.785 \mathrm{~L} / \mathrm{gal} \times 1.0 \mathrm{E}+03 \mathrm{gal} / \mathrm{kgal}$ $\mathrm{x} \mathrm{kg} / 1.0 \mathrm{E}+03 \mathrm{~g} \mathrm{x} .55 .85 \mathrm{~g} / \mathrm{mole}=1,506 \mathrm{~kg}$

Manganese: $\quad 669 \mathrm{~kg}$

Uranium: $\quad 3,209 \mathrm{~kg}$

1959

Iron: $\quad 796 \mathrm{kgal} \times 0.0074 \mathrm{~mole} / \mathrm{L} \times 3.785 \mathrm{~L} / \mathrm{gal} \times 1.0 \mathrm{E}+03 \mathrm{gal} / \mathrm{kgal}$ $\mathrm{x} \mathrm{kg} / 1.0 \mathrm{E}+03 \mathrm{~g} \mathrm{x} 55.85 \mathrm{~g} / \mathrm{mole}=1,245 \mathrm{~kg}$

Manganese: $\quad 553 \mathrm{~kg}$

Uranium: $\quad 473 \mathrm{~kg}$

1964

Iron:

$268 \mathrm{kgal} \times 0.0075 \mathrm{~mole} / \mathrm{L} \times 3.785 \mathrm{~L} / \mathrm{gal} \times 1.0 \mathrm{E}+03 \mathrm{gal} / \mathrm{kgal}$ $\mathrm{x} \mathrm{kg} / 1.0 \mathrm{E}+03 \mathrm{~g} \times 55.85 \mathrm{~g} / \mathrm{mole}=425 \mathrm{~kg}$

Bismuth: $\quad 10.4 \mathrm{~kg}$

Uranium: $\quad 257 \mathrm{~kg}$

1965

Iron: $\quad 745 \mathrm{kgal} \times 0.018 \mathrm{~mole} / \mathrm{L} \times 3.785 \mathrm{~L} / \mathrm{gal} \times 1.0 \mathrm{E}+03 \mathrm{gal} / \mathrm{kgal}$ $\mathrm{x} \mathrm{kg} / 1.0 \mathrm{E}+03 \mathrm{~g} \mathrm{x} 55.85 \mathrm{~g} / \mathrm{mole}=2,835 \mathrm{~kg}$

Bismuth: $\quad 20.6 \mathrm{~kg}$

Uranium: $\quad 521 \mathrm{~kg}$

Total inventories of precipitable metals calculated by the alternate inventory determination method are:

Iron: $\quad 6,010 \mathrm{~kg}$

Bismuth: $\quad 31 \mathrm{~kg}$

Uranium: $\quad 4,460 \mathrm{~kg}$

The inventory values calculated for bismuth, manganese, and uranium are in good agreement with the values listed in Table D3-4. Such agreement supports use of the average of analyte concentration data for tanks 241-S-101, 241-S-104, and 241-S-107 to estimate the inventory of analytes in the sludge in tank 241-SX-111. 


\section{Revision 0}

The real problem is with the widely different iron inventory estimates: $1320 \mathrm{~kg}$ listed in Table D3-4 and 6,000 kg calculated from waste volumes and iron concentrations. There are many possible reasons for the difference in iron inventories: flowsheet iron concentrations too high; iron not completely precipitated; faulty analyses for iron in sludges in tanks 241-S-101, 241-S-104, and 241-S-107, etc. Apparently, the only way to resolve the issue is to sample and analyze sludge from tank 241-SX-111.

Comments and observations concerning comparison of HDW model and independent assessment inventory predictions for various analytes are also made in this section.

\section{Caveat}

The HDW model inventory predictions for tank 241-SX-111 were made on the basis that the solids now in the tank originated from REDOX process HLW and REDOX process salt cake. Independent engineering assessments were made on the basis that solids in the tank originated from REDOX process HLW. This difference in prediction bases should always be kept in mind when comparing HDW model predictions to independent assessment values. 
Revision 0

\section{Inventory Comparisons}

The HDW and the engineering assessment inventories are compared in Table D3-4 and in the observations that follow the table.

Table D3-4. Estimated Analyte Inventories for tank 241-SX-111. (2 Sheets)

\begin{tabular}{|c|c|c|}
\hline Analyte & $\begin{array}{l}\text { HDW model" } \\
(\mathrm{kg})\end{array}$ & $\begin{array}{l}\text { Independent assessment } \\
(\mathrm{kg})\end{array}$ \\
\hline $\mathrm{Al}$ & 79,300 & 82,200 \\
\hline $\mathrm{Bi}$ & 0.228 & $<34.6$ \\
\hline $\mathrm{Ca}$ & 5,050 & 220 \\
\hline $\mathrm{Cl}$ & 1,340 & 1,950 \\
\hline $\mathrm{CO}_{3}$ & 7,600 & NR \\
\hline $\mathrm{Cr}$ & 7,840 & 1,580 \\
\hline$F$ & 1.07 & $<98.7$ \\
\hline $\mathrm{Fe}$ & 32,400 & 1,320 \\
\hline $\mathrm{Hg}$ & 0.0344 & $<0.104$ \\
\hline $\mathrm{K}$ & 340 & 355 \\
\hline $\mathrm{La}$ & 3.74 E-07 & $<8.88$ \\
\hline $\mathrm{Mn}$ & 0.437 & 1,090 \\
\hline $\mathrm{Na}$ & 93,600 & 80,400 \\
\hline $\mathrm{Ni}$ & 1,690 & 97.0 \\
\hline $\mathrm{NO}_{2}$ & 35,600 & 25,000 \\
\hline $\mathrm{NO}_{3}$ & 104,000 & 101,000 \\
\hline $\mathrm{Pb}$ & 5.64 & 27.3 \\
\hline $\mathrm{PO}_{4}$ & 6.71 & $<1,420$ \\
\hline $\mathrm{P}$ & NR & 209 \\
\hline$S$ & NR & 303 \\
\hline $\mathrm{Si}$ & 2,690 & 1,030 \\
\hline $\mathrm{SO}_{4}$ & 1,040 & 1,220 \\
\hline $\mathrm{Sr}$ & NR & 345 \\
\hline TIC as $\mathrm{CO}_{3}$ & 7,600 & 3,400 \\
\hline TOC & 14.3 & 1,420 \\
\hline
\end{tabular}


Table D3-4. Estimated Analyte Inventories for tank 241-SX-111. (2 Sheets)

\begin{tabular}{|c|c|c|}
\hline Analyte & $\begin{array}{l}\text { HDW model } \\
(\mathrm{kg})\end{array}$ & $\begin{array}{l}\text { Independent assessment } \\
(\mathrm{kg})\end{array}$ \\
\hline $\mathrm{Zr}$ & 0.00994 & 55 \\
\hline \multicolumn{3}{|c|}{ Radionuclides $^{\mathfrak{c}}$} \\
\hline${ }^{90} \mathrm{Sr}$ & $2.13 \mathrm{E}+06$ & 240,000 \\
\hline${ }^{137} \mathrm{Cs}$ & 101,000 & 63,800 \\
\hline${ }^{239} \mathrm{Pu}$ & $313 \mathrm{Ci}$ & NR \\
\hline${ }^{238} \mathrm{U}$ & $0.212 \mathrm{Ci}(625 \mathrm{~kg})$ & $2.12 \mathrm{Ci}(6,320 \mathrm{~kg})$ \\
\hline
\end{tabular}

HDW $=$ Hanford Defined Waste

$\mathrm{NR}=$ Not reported

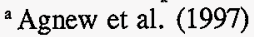

${ }^{\mathrm{b}}$ Average concentration from Table D3-3 multiplied by 0.822

${ }^{\mathrm{c}}$ Radionuclides decayed to January $1,1994$.

\section{Observations}

Aluminum. The HDW model prediction of the aluminum content of tank 241-SX-111 is in excellent agreement with that predicted by the independent assessment. Such agreement is somewhat surprising in that different bases for the waste content of the tank were used for each method; evidently the two bases are not as different as one would expect. The independent assessment prediction is used as the best-basis inventory value.

Bismuth. The HDW model predicts tank 241-SX-111 to only contain $0.228 \mathrm{~kg}$ of bismuth. This result cannot possibly be correct since much of the REDOX process HLW. introduced into the tank contained a small, but measurable, concentration of bismuth. The independent engineering assessment leads to a value of $<34.6 \mathrm{~kg}$ of bismuth in tank 241-SX-111; this value appears very reasonable.

Chromium. The HDW model predicts the waste in tank 241-SX-111 to contain about five times as much chromium as does the independent assessment. This difference reflects, to some extent, the difference in the amounts of chromium in REDOX process HLW assumed to partition to the solid phase. Also, in the HDW model a significant amount of chromium was contributed to the solids in the tank from the REDOX process salt cake assumed to be present in the tank; the independent assessment is made on the basis that REDOX process salt cake is not present in tank $241-\mathrm{SX}-111$. The $1,580 \mathrm{~kg}$ value is accepted as the best-basis inventory estimate. 
Iron. The independent assessment value for the inventory of iron in tank 241-SX-111 is only about one twenty-fifth the amount predicted to be in the tank by the HDW model. The HDW model assumes that the concentration of iron in the REDOX process HLW added to the tank was a factor of five to six times higher than the published Flowsheet 5 and 6 values, $0.048 \mathrm{M}$ versus $0.0075 \mathrm{M}$. The value of $1,320 \mathrm{~kg}$ iron is selected as the best-estimate inventory number even though a separate analysis, based upon the volume of waste added to the tank and the estimated concentration of iron in the waste, indicates that the iron content of tank 241-SX-111 could be as high as $6,000 \mathrm{~kg}$.

Manganese. The HDW model (Rev. 4) predicts that tank 241-SX-111 contains only $0.437 \mathrm{~kg}$ of manganese. This value is absurdly low considering the presence of at least $0.0034 M$ manganese in most of the REDOX process HLW added to the tank. Manganese surely would have precipitated when REDOX process HLW was made alkaline. The bestestimate value for the manganese inventory of tank $241-\mathrm{SX}-111$ is $1,090 \mathrm{~kg}$, a value derived in the independent assessment.

Nickel. The independent assessment predicts only $97 \mathrm{~kg}$ of nickel in tank 241-SX-111 whereas the HDW model prediction is $1,690 \mathrm{~kg}$. The HDW model nickel inventory likely reflects an incorrect assumption concerning the amount of corrosion of stainless steel equipment in the REDOX plant.

Nitrate. The independent engineering assessment based upon the assumption that tank 241-SX-111 contains only REDOX process HLW sludge leads to a nitrate inventory of $101,000 \mathrm{~kg}$. The HDW model based upon the assumption that tank 241-SX-111 contains both REDOX process HLW sludge and REDOX process salt cake predicts that the tank contains $104,000 \mathrm{~kg}$ of nitrate. The latter result is certainly the expected one from the assumption that salt cake containing a large concentration of soluble nitrates is present in the tank. For consistency, the independent engineering assessment value of $101,000 \mathrm{~kg}$ nitrate is used as the best-basis estimate.

Potassium. The independent assessment predicts tank 241-SX-111 to contain $355 \mathrm{~kg}$ of potassium whereas the HDW model predicts only $340 \mathrm{~kg}$ of potassium are present. The $\mathrm{HDW}$ model did not take into account potassium added as $\mathrm{KMnO}_{4}$ (see discussion on manganese); even so, both predictions are in splendid, likely fortuitous agreement. The independent assessment value of $355 \mathrm{~kg}$ is selected as the best-basis estimate of the inventory of potassium in tank 241-SX-111.

Sodium. The HDW model predicts the sodium content of tank 241-SX-111 is $93,600 \mathrm{~kg}$ whereas the independent engineering assessment described in this section leads to a value of $80,400 \mathrm{~kg}$. These two values are in good agreement considering that both approaches used a different basis for making inventory predictions. Perhaps the two approaches are not as different as first appears. One disturbing note is that the HDW model would be expected to predict considerably more sodium inventory than the engineering assessment approach since REDOX process salt cake is known to contain a high 


\section{Revision 0}

concentration of nitrate (Schulz 1980). The independent engineering assessment inventory of $80,400 \mathrm{~kg}$ sodium is chosen as the best-basis estimate for tank 241-SX-111.

Sulfate. The predictions of the sulfate content of tank 241-SX-111 by the HDW model and the independent engineering assessment, $1,040 \mathrm{~kg}$ versus $1,220 \mathrm{~kg}$, are in remarkably good agreement. It is not known if this agreement is completely fortuitous or whether the choices of bases for predicting the content of this tank are not that different.

Total Hydroxide. Once the best-basis inventories were determined, the hydroxide inventory was calculated by performing a charge balance with the valences of other analytes. In some cases, this approach requires that other analyte (e.g., sodium or nitrate) inventories be adjusted to achieve the charge balance. During such adjustments, the number of significant figures is not increased. No such adjustments were needed in this tank. This charge balance approach is consistent with that used by Agnew et al. (1997).

Uranium. The HDW model predicts the waste in tank 241-SX-111 to only contain $0.212 \mathrm{Ci}(625 \mathrm{~kg})$ of uranium whereas the independent assessment predicts that $6,320 \mathrm{~kg}$ of uranium are present in the tank. In any case, the value predicted by the independent assessment, $6,320 \mathrm{~kg}$, is taken as the best-basis estimate of the uranium content of tank 241-SX-111: 
HNF-SD-WM-ER-682

Revision 0

\section{D4.0 DEFINE THE BEST-BASIS AND ESTABLISH COMPONENT INVENTORIES}

Information about chemical, radiological, and/or physical properties is used to perform safety analyses, engineering evaluations, and risk assessment associated with waste management activities, as well as regulatory issues. These activities include overseeing tank farm operations and identifying, monitoring, and resolving safety issues associated with these operations and with the tank wastes. Disposal activities involve designing equipment, processes and facilities for retrieving wastes and processing them into a form that is suitable for long-term storage.

Chemical and radiological inventory information are generally derived using three approaches: (1) component inventories are estimated using the results of sample analyses, (2) component inventories are predicted using the HDW Model based on process knowledge and historical information, or (3) a tank-specific process estimate is made based on process flowsheets, reactor fuel data, essential material usage, and other operating data.

An effort is underway to provide waste inventory estimates that will serve as standard characterization source terms for the various waste management activities (Hodgson and LeClair 1996). As part of this effort, an evaluation of chemical information for tank 241-SX-111 was performed, and a best basis inventory was established. This work, detailed in the following sections, follows the methodology that was established by the standard inventory task. The following information was utilized as part of this evaluation:

- Inventory estimates generated by HDW model (Agnew et al. 1997)

- Average of analyte concentrations in REDOX process HLW sludges in tanks 241-S-101, 241-S-104, and 241-S-107

- Inventory estimates generated by a tank-specific assessment process utilizing chemical process flowsheets and a detailed historical tank waste transaction data base.

The results from this evaluation support using a predicted inventory based primarily on results from a tank-specific assessment process utilizing the average of analyte concentrations for REDOX process waste sludges in tanks 241-S-101 (Kruger et al. [1996]), 241-S-104 (DiCenso et al. [1994]), and 241-S-107 (Simpson et al. [1996]) for the following reasons:

1. The waste in tank 241-SX-111 has not been analyzed; it is not possible to use a predicted inventory based on analytical results.

2. The tank-specific assessment correctly predicts, based upon a careful and meticulous review of historical waste transaction records, that only REDOX process HLW of all the wastes introduced into tank 241-SX-111, contributed to the solid waste in the tank. 
3. The HDW model incorrectly attributes part of the solids now in tank 241-SX-111 to salt cake precipitated from one addition of concentrated REDOX process HLW supernatant. Such analysis ignores the large volumes of water that were added to the tank subsequent to precipitation of any salt cake solids. Experimental evidence exists (Schulz 1980) that strongly suggests any precipitated salt cake would have readily dissolved.

Best-basis tank inventory values are derived for 46 key radionuclides (as defined in Section 3.1 of Kupfer et al. 1997), all decayed to a common report date of January 1, 1994. Often, waste sample analyses have only reported ${ }^{90} \mathrm{Sr},{ }^{137} \mathrm{Cs},{ }^{239 / 240} \mathrm{Pu}$, and total uranium (or total beta and total alpha), while other key radionuclides such as ${ }^{60} \mathrm{Co},{ }^{99} \mathrm{Tc},{ }^{129} \mathrm{I},{ }^{154} \mathrm{Eu},{ }^{155} \mathrm{Eu}$, and ${ }^{241} \mathrm{Am}$, etc., have been infrequently reported. For this reason it has been necessary to derive most of the 46 key radionuclides by computer models. These models estimate radionuclide activity in batches of reactor fuel, account for the split of radionuclides to various separations plant waste streams, and track their movement with tank waste transactions. (These computer models are described in Kupfer et al. 1997, Section 6.1 and in Watrous and Wootan 1997.) Model generated values for radionuclides in any of 177 tanks are reported in the HDW Rev. 4 model results (Agnew et al. 1997). The best-basis value for any one analyte may be either a model result or a sample or engineering assessment-based result if available. (No attempt has been made to ratio or normalize model results for all 46 radionuclides when values for measured radionuclides disagree with the model.) For a discussion of typical error between model derived values and sample derived values, see Kupfer et al. 1997, Section 6.1.10.

The inventory values reported in Tables D4-1 and D4-2 are subject to change. Refer to the Tank Characterization Database (TCD) for the most current inventory values. 
Table D4-1. Best-Basis Inventory Estimates for Nonradioactive Components in Tank 241-SX-111 (Effective March 10, 1997). (2 Sheets)

\begin{tabular}{|c|c|c|c|}
\hline Analyte & $\begin{array}{c}\text { Total inventory } \\
(\mathrm{kg})\end{array}$ & $\begin{array}{c}\text { Basis } \\
(\mathrm{S}, \mathrm{M}, \mathrm{E} \text { or } \mathrm{C})^{1}\end{array}$ & Comment \\
\hline Al & 82,200 & E & \\
\hline $\mathrm{Bi}$ & $<34.6$ & $\mathrm{E}$ & \\
\hline $\mathrm{Ca}$ & $220^{\circ}$ & $\mathrm{E}$ & 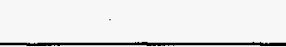 \\
\hline $\mathrm{Cl}$ & 1,950 & E & \\
\hline TIC as $\mathrm{CO}_{3}$ & 3,400 & $E$ & \\
\hline $\mathrm{Cr}$ & 1,580 & E & \\
\hline $\mathrm{F}$ & $<98.7$ & $\mathrm{E}$ & \\
\hline $\mathrm{Fe}$ & 1,320 & E & \\
\hline $\mathrm{Hg}$ & $<0.104$ & $\mathrm{E}$ & \\
\hline $\mathrm{K}$ & 355 & $\mathrm{E}$ & \\
\hline $\mathrm{La}$ & $<8.88$ & $E$ & \\
\hline $\mathrm{Mn}$ & 1,090 & $\mathrm{E}$ & \\
\hline $\mathrm{Na}$ & 80,400 & $E$ & \\
\hline $\mathrm{Ni}$ & 97 & $\mathrm{E}$ & \\
\hline $\mathrm{NO}_{2}$ & 25,000 & E & \\
\hline $\mathrm{NO}_{3}$ & 101,000 & $\mathrm{E}$ & \\
\hline $\mathrm{OH}_{\text {TOTAL }}$ & 174,000 & $\mathrm{C}$ & \\
\hline $\mathrm{Pb}$ & 27.3 & $\mathrm{E}$ & \\
\hline $\mathrm{PO}_{4}$ & $<1,420$ & E & \\
\hline $\mathrm{Si}$ & 1,030 & $\mathrm{E}$ & \\
\hline $\mathrm{SO}_{4}$ & 1,220 & $\mathrm{E}$ & \\
\hline $\mathrm{Sr}$ & 345 & $\mathrm{E}$ & \\
\hline TOC & 1,420 & $\mathrm{E}$ & \\
\hline
\end{tabular}


HNF-SD-WM-ER-682

Revision 0

Table D4-1. Best-Basis Inventory Estimates for Nonradioactive Components in Tank 241-SX-111 (Effective March 10, 1997). (2 Sheets)

\begin{tabular}{|c|c|c|c|}
\hline Analyte & $\begin{array}{c}\text { Total inventory } \\
(\mathrm{kg})\end{array}$ & $\begin{array}{c}\text { Basis } \\
(\mathrm{S}, \mathrm{M}, \mathrm{E} \text { or } \mathrm{C})^{\mathrm{\perp}}\end{array}$ & Comment \\
\hline $\mathrm{U}_{\text {TOTAL }}$ & 6,320 & $\mathrm{E}$ & \\
\hline $\mathrm{Zr}$ & 55 & $\mathrm{E}$ & \\
\hline
\end{tabular}

${ }^{1} \mathrm{~S}=$ Sample-based

$M=$ Hanford Defined Waste model-based, Agnew et al. (1997)

$\mathrm{E}=$ Engineering assessment-based

$\mathrm{C}=$ Calculated by charge balance; includes oxides as hydroxides, not including $\mathrm{CO}_{3}$, $\mathrm{NO}_{2}, \mathrm{NO}_{3}, \mathrm{PO}_{4}, \mathrm{SO}_{4}$, and $\mathrm{SiO}_{3}$. 


\section{Revision 0}

Table D4-2. Best-Basis Inventory Estimates for Radioactive Components in Tank 241-SX-111 Decayed to January 1, 1994 (Effective March 10, 1997). (2 Sheets)

\begin{tabular}{|c|c|c|l|}
\hline Analyte & $\begin{array}{c}\text { Total inventory } \\
(\mathrm{Ci})\end{array}$ & $\begin{array}{c}\text { Basis } \\
(\mathrm{S}, \mathrm{M}, \text { or } \mathrm{E})\end{array}$ & Comment \\
\hline${ }^{1} \mathrm{H}$ & 62.9 & $\mathrm{M}$ & \\
\hline${ }^{14} \mathrm{C}$ & 3.16 & $\mathrm{M}$ & \\
\hline${ }^{59} \mathrm{Ni}$ & 16 & $\mathrm{M}$ & \\
\hline${ }^{60} \mathrm{Co}$ & 2.88 & $\mathrm{M}$ & \\
\hline${ }^{63} \mathrm{Ni}$ & 1,570 & $\mathrm{M}$ & \\
\hline${ }^{79} \mathrm{Se}$ & 6.59 & $\mathrm{M}$ & \\
\hline${ }^{90} \mathrm{Sr}$ & 240,000 & $\mathrm{E}$ & \\
\hline${ }^{90} \mathrm{Y}$ & 240,000 & $\mathrm{E}$ & \\
\hline${ }^{93} \mathrm{Zr}$ & 28.2 & $\mathrm{M}$ & \\
\hline${ }^{93 \mathrm{~m}} \mathrm{Nb}$ & 26.0 & $\mathrm{M}$ & \\
\hline${ }^{99} \mathrm{Tc}$ & 24.7 & $\mathrm{M}$ & \\
\hline${ }^{106} \mathrm{Ru}$ & $6.77 \mathrm{E}-04$ & $\mathrm{M}$ & \\
\hline${ }^{113 \mathrm{~m}} \mathrm{Cd}$ & 13 & $\mathrm{M}$ & \\
\hline${ }^{125} \mathrm{Sb}$ & 10.3 & $\mathrm{M}$ & \\
\hline${ }^{126} \mathrm{Sn}$ & 8.63 & $\mathrm{M}$ & \\
\hline${ }^{129} \mathrm{I}$ & 0.0468 & $\mathrm{M}$ & \\
\hline${ }^{154} \mathrm{Cs}$ & 0.747 & $\mathrm{M}$ & \\
\hline${ }^{137} \mathrm{Cs}$ & 63,800 & $\mathrm{E}$ & \\
\hline${ }^{137 m} \mathrm{Ba}$ & 60,400 & $\mathrm{E}$ & \\
\hline${ }^{151} \mathrm{Sm}$ & 23,600 & $\mathrm{M}$ & \\
\hline${ }^{152} \mathrm{Eu}$ & 19.9 & $\mathrm{M}$ & \\
\hline${ }^{154} \mathrm{Eu}$ & 69.3 & $\mathrm{M}$ & \\
\hline${ }^{155} \mathrm{Eu}$ & 1,010 & $\mathrm{M}$ & \\
\hline${ }^{226} \mathrm{Ra}$ & 0.0014 & $\mathrm{M}$ & \\
\hline${ }^{227} \mathrm{Ac}$ & 0.00633 & $\mathrm{M}$ & \\
\hline${ }^{228} \mathrm{Ra}$ & 0.00250 & $\mathrm{M}$ & \\
\hline${ }^{229} \mathrm{Th}$ & $6.22 \mathrm{E}-05$ & $\mathrm{M}$ & \\
\hline${ }^{231} \mathrm{~Pa}$ & 0.00742 & $\mathrm{M}$ & \\
\hline
\end{tabular}




\section{HNF-SD-WM-ER-682}

\section{Revision 0}

Table D4-2. Best-Basis Inventory Estimates for Radioactive Components in Tank 241-SX-111 Decayed to January 1, 1994 (Effective March 10, 1997). (2 Sheets)

\begin{tabular}{|c|c|c|l|}
\hline Analyte & $\begin{array}{c}\text { Total inventory } \\
(\mathrm{Ci})\end{array}$ & $\begin{array}{c}\text { Basis } \\
(\mathrm{S}, \mathrm{M}, \text { or } \mathrm{E})^{1}\end{array}$ & Comment \\
\hline${ }^{232} \mathrm{Th}$ & $3.36 \mathrm{E}-05$ & $\mathrm{M}$ & \\
\hline${ }^{232} \mathrm{U}$ & 0.0112 & $\mathrm{M}$ & \\
\hline${ }^{233} \mathrm{U}$ & 0.0428 & $\mathrm{M}$ & \\
\hline${ }^{234} \mathrm{U}$ & 0.243 & $\mathrm{M}$ & \\
\hline${ }^{235} \mathrm{U}$ & 0.00981 & $\mathrm{M}$ & \\
\hline${ }^{236} \mathrm{U}$ & 0.0102 & $\mathrm{M}$ & \\
\hline${ }^{237} \mathrm{~Np}$ & 0.107 & $\mathrm{M}$ & \\
\hline${ }^{238} \mathrm{Pu}$ & 13.1 & $\mathrm{M}$ & \\
\hline${ }^{238} \mathrm{U}$ & 2.12 & $\mathrm{E}$ & \\
\hline${ }^{239} \mathrm{Pu}$ & 313 & $\mathrm{M}$ & \\
\hline${ }^{240} \mathrm{Pu}$ & 56.5 & $\mathrm{M}$ & \\
\hline${ }^{241} \mathrm{Am}$ & 361 & $\mathrm{M}$ & \\
\hline${ }^{241} \mathrm{Pu}$ & 643 & $\mathrm{M}$ & \\
\hline${ }^{242} \mathrm{Cm}$ & 0.849 & $\mathrm{M}$ & \\
\hline${ }^{242} \mathrm{Pu}$ & 0.00361 & $\mathrm{M}$ & \\
\hline${ }^{243} \mathrm{Am}$ & 0.0160 & $\mathrm{M}$ & \\
\hline${ }^{243} \mathrm{Cm}$ & 0.0839 & $\mathrm{M}$ & \\
\hline${ }^{244} \mathrm{Cm}$ & 2.52 & $\mathrm{M}$ & \\
\hline
\end{tabular}

${ }^{1} \mathrm{~S}=$ Sample-based

$M=$ Hanford Defined Waste model-based, Agnew et al. (1997)

$\mathrm{E}=$ Engineering assessment-based. 
HNF-SD-WM-ER-682

Revision 0

\section{D5.0 APPENDIX D REFERENCES}

Agnew, S. F., R. A. Corbin, T. B. Duran, K. A. Jurgensen, T. P. Ortiz, and B. L. Young, 1995, Waste Status and Transaction Record Summary (WSTRS Rev. 2),

WHC-SD-WM-TI-615, -614, -669, -689, Rev. 2, Los Alamos National Laboratory, Los Alamos, New Mexico.

Agnew, S. F., J. Boyer, R. A. Corbin, T. B. Duran, J. R. FitzPatrick, K. A. Jurgensen, T. P. Ortiz, and B. L. Young, 1997, Hanford Tank Chemical and Radionuclide Inventories: HDW Model Rev. 4, LA-UR-96-3860, Los Alamos National Laboratory, Los Alamos, New Mexico.

Allen, G. K., 1976, Estimated Inventory of Chemicals Added to Underground Waste Tanks, 1944 Through 1975, ARH-CD-6108, Atlantic Richfield Hanford Company, Richland, Washington.

Anderson, J. D., 1990, A History of the 200 Area Farms, WHC-MR-0132, Westinghouse Hanford Company, Richland, Washington.

DiCenso, A. T., L. C. Amato, J. D. Franklin, G. L. Nuttall, K. W. Johnson, P. Sathyanarayana, and B. C. Simpson, 1994, Tank Characterization Report for SingleShell Tank 241-S-104, WHC-SD-WM-ER-370, Rev. 0, Westinghouse Hanford Company, Richland, Washington.

Hanlon, B. M., 1996, Waste Tank Summary Report for Month Ending May 31, 1996, WHC-EP-182-99, Westinghouse Hanford Company, Richland, Washington.

Hodgson, K. M., and M. D. LeClair, 1996, Work Plan for Defining a Standard Inventory Estimate for Wastes Stored in Hanford Site Underground Tanks, WHC-SD-WM-WP-311, Rev. 1, Lockheed Martin Hanford Corporation, Richland, Washington.

Hu, T. A., L. C. Amato, R. T. Winward, and R. D. Cromar, 1997, Tank Characterization Report for Single-Shell Tank 241-U-102, HNF-SD-WM-ER-618, Rev. O, Lockheed Martin Hanford Corporation, Richland, Washington

Kruger, A. A., B. J. Morris, and L. J. Fergestrom, 1996, Tank Characterization Report for Single-Shell Tank 241-S-101, WHC-SD-WM-ER-613, Rev. 0, Westinghouse Hanford Company, Richland, Washington. 
Kupfer, M. J., A. L. Boldt, B. A. Higley, K. M. Hodgson, L. W. Shelton, B. C. Simpson, and R. A. Watrous (LMHC), S. L. Lambert, and D. E. Place (SESC), R. M. Orme (NHC), G. L. Borsheim (Borsheim Associates), N. G. Colton (PNNL), M. D. LeClair (SAIC), R. T. Winward (Meier Associates), and W. W. Schulz (W'S Corporation), 1997, Standard Inventories of Chemicals and Radionuclides in Hanford Site Tank Wastes, HNF-SD-WM-TI-740, Rev. 0, Lockheed Martin Hanford Corporation, Richland, Washington.

Kupfer, M. J., and W. W. Schulz, 1997, Tank Characterization Report for Single-Shell Tank 241-SX-108, WHC-SD-WM-ER-582, Rev. 0A, Lockheed Martin Hanford Corporation, Richland, Washington.

Schulz, W. W., 1980, Removal of Radionuclides from Hanford Defense Waste Solutions, RHO-SA-51, Rockwell Hanford Company, Richland, Washington.

Simpson, B. C., D. S. Daly, D. W. Engel, and J. G. Field, 1996, Tank Characterization Report for Single-Shell Tank 241-S-107, WHC-SD-WM-ER-589, Rev. 0, Westinghouse Hanford Company, Richland, Washington.

Watrous, R. A., and D. W. Wootan, 1997, Activity of Fuel Batches Precessed Through Hanford Separations Plants, 1994 through 1989, HNF-SD-WM-TI-794, Rev. 0, Lockheed Martin Hanford Corporation, Richland, Washington. 
HNF-SD-WM-ER-682

Revision 0

This page intentionally left blank. 